\title{
The relationship between waist circumference on obesity and prevalence of type 2 diabetes mellitus in male patients in the Regional Public Hospital of Tabanan Regency
}

\author{
L G Evayanti ${ }^{1 *}$, B G A D Hendra ${ }^{1}$, S H Indonesiani ${ }^{1}$ \\ ${ }^{1}$ Faculty of Medicine and Health Sciences, Universitas Warmadewa, Denpasar, Bali \\ *luhgdeevayanti@gmail.com
}

\begin{abstract}
Obesity is a major factor of type 2 diabetes mellitus (DM). The measurement of waist circumference is one method to diagnose obesity. The aim of this study was to determine the relationship between waist circumference on obesity and prevalence of type $2 \mathrm{DM}$ in male patients in the Regional Public Hospital of Tabanan Regency. The design of this study was cross-sectional study. The subjects of this study were all adult male patients with type 2 diabetes mellitus or obesity in Internal Medicine Clinic in the Regional Public Hospital of Tabanan Regency, who were selected using consecutive sampling (September - December 2017). Waist circumference was measured by cloth measuring tape. Random blood glucose level was measured using finger prick blood glucose tests (Easy Touch GCU). Data were analyzed by SPSS application using Chisquare test $(\mathrm{p}$ value $<0.05)$. Based on the results of this study shown that there was significant relationship between obesity and type $2 \mathrm{DM}(\mathrm{p}<0.05 ; \mathrm{r}=0.396)$. Waist circumference appeared more evidently related with type $2 \mathrm{DM}$. Our findings provide useful information for the projection of increasing prevalence of type $2 \mathrm{DM}$ in male patients.
\end{abstract}

Keyword : Relationship, Prevalence, Public Hospital.

\section{Introduction}

Type 2 diabetes mellitus (T2DM) is a metabolic disease characterized by hyperglycemia resulting from a combination of resistance to insulin action and an inadequate compensatory insulin secretory response. The long term complications of diabetes mellitus is associated with long-term damage, dysfunction, and failure of different organs, especially the eyes, kidneys, nerves, heart, and blood vessels [1]. Diabetes mellitus is one of health problems in developing countries, especially Indonesia. In 2013, the prevalence of diabetes mellitus in Indonesia is 12.191.564 people (aged > 15 years in urban areas) [2]. In the Regional Public Hospital of Tabanan Regency, the prevalence of diabetes mellitus was increased from 174 patients (2014) to 280 patients (2015). Hyperglycemia can cause pathologic and functional changes in various target tissues, but without clinical symptoms, may be present for a long period of time before diabetes mellitus is detected [3].

Type 2 diabetes mellitus is associated with obesity. Body mass index is general indicator of obesity, but not reliable for distribution of obesity [4]. Waist circumference is a method to assess central obesity and also strongly correlated with T2DM in European and Asian adults [5]. While changes in body mass index have been well documented in the Regional Public 
Hospital of Tabanan Regency, changes in waist circumference are not well described. The purpose of this study is determine the relationship between waist circumference on obesity and prevalence of T2DM in male patients in the Regional Public Hospital of Tabanan Regency.

\section{Method}

The design of this study was cross-sectional study. The participants were all adult male patients with type 2 diabetes mellitus or obesity in Internal Medicine Clinic in the Regional Public Hospital of Tabanan Regency, who were selected using consecutive sampling (September - December 2017). Waist circumference, recorded to the nearest $0.1 \mathrm{~cm}$, was taken with a cloth measuring tape and was measured on bare skin at the midline between the lower border of the ribs and the iliac crest in the horizontal plane after a normal expiration. Previously diagnosed type $2 \mathrm{DM}$ was identified by medical records and then confirmed using random blood glucose level. Random blood glucose level was measured using finger prick blood glucose tests (Easy Touch GCU). Both of measurements were recorded by trained staff. Data were analyzed by SPSS application using Chi-square test ( $\mathrm{p}$ value $<0.05$ ).

\section{Results And Discussion}

The number of participants in this study was 53 people. The characteristics of male participants in the Regional Public Hospital of Tabanan Regency were shown in Table 1.

Table 1. Characteristics of male participants

\begin{tabular}{lcc}
\hline \multicolumn{1}{c}{ Parameters } & Frequency $(\mathbf{n}=\mathbf{5 3})$ & Percentage (\%) \\
\hline Age range (years) & 9 & \\
$21-30$ & 15 & 17.0 \\
$31-40$ & 24 & 28.3 \\
$41-50$ & 5 & 45.3 \\
$51-60$ & & 9.4 \\
Waist circumference & 28 & \\
Obese patients & 25 & 52.8 \\
Non-obese patients & & 47.2 \\
Family history of DM & 23 & \\
Yes & 30 & 43.4 \\
No & & 56.6 \\
Patient history of Type 2 DM & 29 & \\
Yes & 24 & 54.7 \\
No & & 45.3 \\
\hline
\end{tabular}

The number of type $2 \mathrm{DM}$ participants with obesity was higher than the number of type 2 DM participants without obesity. Based on the results of this study shown that there was significant relationship between obesity and type $2 \mathrm{DM}(\mathrm{p}<0.05 ; \mathrm{r}=0.396)$. The relationship between waist circumference and type $2 \mathrm{DM}$ was shown in table 2. 
Table 2. The relationship between waist circumference and type $2 \mathrm{DM}$ in male participants

\begin{tabular}{llcccc}
\hline & & \multicolumn{2}{c}{ Type 2 Diabetes Mellitus } & & \\
\cline { 3 - 4 } \multicolumn{1}{c}{ Parameters } & Yes & No & & Total & p Value \\
\hline \multirow{3}{*}{ Waist } & Obese & 21 & 7 & 28 & \\
Circumference & patients & $(75 \%)$ & $(25 \%)$ & $(100 \%)$ & 0.02 \\
& Non-obese & 8 & 17 & 25 & \\
& patients & $(32 \%)$ & $(68 \%)$ & $(100 \%)$ & \\
\hline \multicolumn{2}{c}{ Total } & $29(54.7 \%)$ & $24(45.3 \%)$ & $53(100 \%)$ & \\
\hline
\end{tabular}

The risk factors of type $2 \mathrm{DM}$ include age, family history of DM, lifestyle, obesity, and others. People over 40 years old are more diagnosed with type 2 DM than people under 40 years old [6]. Body metabolism on old age tends to decrease [7]. In addition, decreased activity and increased food consumption can cause type $2 \mathrm{DM}$ on old age. Fat distribution can be measured by waist circumference and waist-to-hip ratio [8]. Based on this study, waist circumference on obesity and type $2 \mathrm{DM}$ had positive relationship significantly $(\mathrm{p}<0.05 ; \mathrm{r}=$ 0.396). In other study, there was significant relationship between waist circumference and risk of type 2 DM, particularly among persons of low or normal weight [9]. Sofiana reported that people with waist circumference exceeding normal risk 8.419 times suffer from DM than people with normal waist circumference [10]. Waist circumference may be a better indicators than waist-to-hip ratio for risk of diabetes. Chan et al. reported that there was strong positive association between overall obesity as measured by body mass index (BMI) and risk of diabetes with multivariate relative risks of 42.1 (95\% confidence interval 22.0-80.6). Waist circumference was positively associated with the risk of type 2 diabetes among the top $20 \%$ of the cohort, while waist-to-hip ratio was a good predictor of type 2 diabetes only among the top $5 \%[8]$.

Accumulating evidence supports abdominal fat associated with insulin resistance. Dysfunctions of adipokine pathways often result metabolic abnormalities in multiple tissues thereby constituting a critical pathological component in the development of metabolic disease on obese people [11]. M1 macrophages secrete adipocytokines and produce reactive oxygen species, which induce insulin resistance. Adipocytokines are abundantly expressed in visceral fat tissue such as TNF $\alpha$ and IL-6 [12]. Furthermore, adiponectin are expressed lower than adipocytokines in obese people [13]. Harke et al. reported that abdominal obesity in diabetic females correlates with altered levels of adipocytokines [14].

\section{Conclusions}

In summary, this study reported that waist circumference on obesity and type $2 \mathrm{DM}$ have positive relationship significantly in the Regional Public Hospital of Tabanan Regency. Waist circumference were good indicator for the relationship between abdominal adiposity and risk of diabetes.

\section{Acknowledgement}

The authors would like to thank to Faculty of Medicine and Health Sciences, Universitas Warmadewa and The Regional Public Hospital of Tabanan Regency have provided support during the process of this study. 


\section{References}

[1] Kharroubi A T and Darwish H M 2015 Diabetes mellitus: The epidemic of the century World J Diabetes 6(6) p 850-867

[2] Departemen Kesehatan RI 2013 Riset Kesehatan Dasar Available from: http://labmandat.litbang. depkes.go.id/images/download/laporan/RKD/2013/Laporan_riskesdas_2013_final.pdf [Acessed: April 21, 2019]

[3] American Diabetes Association 2010 Diagnosis and Classification of Diabetes Mellitus Diabetes Care 33(Suppl 1) p S62-S69

[4] Kok P, Seidell J C, and Meinders A E 2004 The Value and Limitations of the Body Mass Index (BMI) in the Assessment of the Health Risks of Overweight and Obesity Ned Tijdschr Geneeskd 148 p 2379-82

[5] Ruan Y, Mo M, Joss-Moore L, Li Y Y, Yang Q D, Zhang H, Li R, and Xu W H 2003 Increased Waist Circumference and Prevalence of Type 2 Diabetes and Hypertension in Chinese adults: Two Population-Based Cross-Sectional Surveys in Shanghai, China BMJ Open $3 \mathrm{p} \mathrm{e} 003408$

[6] Fletcher B, Gulanick M, and Lamendola C 2002 Risk Factors for Type 2 Diabetes Mellitus The Journal of Cardiovascular Nursing 16(2) p 17-23

[7] Harris M I, Flegal K M, Cowie C C, Eberhardt M S, Glodstein D E, Wiedmeyer H M, and Byrd-Hott D D 1998 Prevalence of Diabetes, Impaired Fasting Glucose, and Impaired Glucose Tolerance in U.S. Adults. The Third National Health and Nutrition Examination Survey, 1988 1994 Diabetes Care 21 p 518-524

[8] Chan J M, RImm E B, Colditz G A, Stampfer M J, and Willet W C 1994 Obesity, Fat Distribution, and Weight Gain as Risk Factors for Clinical Diabetes in Men Diabetes Care 17(9) p 961-969

[9] Feller S, Boeing H, and Pischon T 2010 Body Mass Index, Waist Circumference, and the Risk of Type 2 Diabetes Mellitus: Implications for Routine Clinical Practice Dtsch Arztebl Int 107(26) p 470-476

[10] Sofiana L 2014 Hubungan Lingkar Pinggang dengan Kadar Gula Darah pada Orang yang Berisiko Diabetes Mellitus Tipe 2 Usia Dewasa di Gandu Sendangtirto Berbah Sleman Yogyakarta. Yogyakarta: Sekolah Tinggi Ilmu Kesehatan 'Aisyiyah

[11] Trujillo M E and Scherer P E 2006 Adipose tissue-derived factors: impact on health and disease Endocr Rev 27 p 762-778

[12] Cao H 2014 Adipocytokines in Obesity and Metabolic Disease J Endocrinol 220(2) p T47-T59

[13] Ouchi N, Ohashi K, Shibata R and Murohara T 2012 Adcytokines and obesity-linked disorders Nagoya J Med Sci 74(1-2) p 19-30

[14] Harke S M, Khadke S P, Ghadge A A, Manglekar A S, Shah S S, Diwan A G, and Kuvalekar A A 2017 Adipocytokines and Anthropometric Measures in Type 2 Diabetics Diabetes \& Metabolic Syndrome: Clinical Research \& Reviews 11(1) p S273-S276 